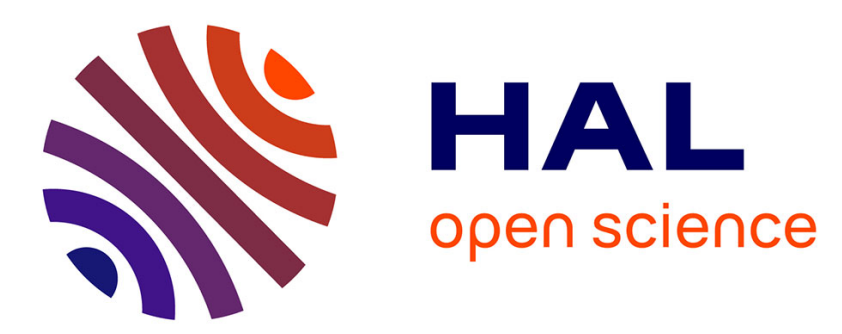

\title{
Aberrant GPCR expression is a sufficient genetic event to trigger adrenocortical tumorigenesis
}

\author{
T.L. Mazzuco, O. Chabre, J.J. Feige, M. Thomas
}

\section{To cite this version:}

T.L. Mazzuco, O. Chabre, J.J. Feige, M. Thomas. Aberrant GPCR expression is a sufficient genetic event to trigger adrenocortical tumorigenesis. Molecular and Cellular Endocrinology, 2009, 265-266, pp.23. 10.1016/j.mce.2006.12.034 . hal-00531906

\section{HAL Id: hal-00531906 https://hal.science/hal-00531906}

Submitted on 4 Nov 2010

HAL is a multi-disciplinary open access archive for the deposit and dissemination of scientific research documents, whether they are published or not. The documents may come from teaching and research institutions in France or abroad, or from public or private research centers.
L'archive ouverte pluridisciplinaire HAL, est destinée au dépôt et à la diffusion de documents scientifiques de niveau recherche, publiés ou non, émanant des établissements d'enseignement et de recherche français ou étrangers, des laboratoires publics ou privés. 


\section{Accepted Manuscript}

Title: Aberrant GPCR expression is a sufficient genetic event to trigger adrenocortical tumorigenesis

Authors: T.L. Mazzuco, O. Chabre, J.J. Feige, M. Thomas

PII: $\quad$ S0303-7207(06)00586-7

DOI: $\quad$ doi:10.1016/j.mce.2006.12.034

Reference: $\quad$ MCE 6575

To appear in: $\quad$ Molecular and Cellular Endocrinology

Please cite this article as: Mazzuco, T.L., Chabre, O., Feige, J.J., Thomas, M., Aberrant GPCR expression is a sufficient genetic event to trigger adrenocortical tumorigenesis, Molecular and Cellular Endocrinology (2006), doi:10.1016/j.mce.2006.12.034

This is a PDF file of an unedited manuscript that has been accepted for publication. As a service to our customers we are providing this early version of the manuscript. The manuscript will undergo copyediting, typesetting, and review of the resulting proof before it is published in its final form. Please note that during the production process errors may be discovered which could affect the content, and all legal disclaimers that apply to the journal pertain. 


\section{ABERRANT GPCR EXPRESSION IS A SUFFICIENT GENETIC EVENT TO}

\section{TRIGGER ADRENOCORTICAL TUMORIGENESIS}

T L Mazzuco ${ }^{1,2,3 *}$, O Chabre ${ }^{1,2,3}$, JJ Feige ${ }^{1,2} \&$ M Thomas ${ }^{1,2}$.

${ }^{1}$ Institut National de la Santé et de la Recherche Médicale, Equipe Mixte 105, Grenoble, France; ${ }^{2}$ Commissariat à 1'Energie Atomique, Département Réponse et Dynamique Cellulaires, Grenoble, France and ${ }^{3}$ Service d'Endocrinologie, Département de Diabétologie, Urologie, Néphrologie et Endocrinologie, Centre Hospitalier Universitaire, Grenoble, France.

* Present address: Departamento de Farmacologia, CCB Bloco D, Universidade Federal de Santa Catarina, Caixa Postal 476, CEP 88049-900 Florianópolis, SC, Brazil.

Corresponding author: Michaël Thomas, INSERM, Equipe Mixte 105, DRDC, CEA-G, 17 rue des Martyrs, 38054 Grenoble, Cedex 09, France. Tel: 01-438-78-44-64; Fax: 01438-78-50-58; e-mail: michael.thomas@,cea.fr. 
Keywords : GPCR receptor; hypercortisolism ; adrenal tumorigenesis ; hyperplasia; Cushing syndrome; xenotransplantation

\begin{abstract}
Aberrant expression of $\mathrm{G}$ protein-coupled receptors (GPCR) in the adrenal cortex is observed in some cases of ACTH-independent macronodular adrenal hyperplasias and adenomas associated with Cushing syndrome. Although there is clinical evidence for the implication of these receptors in abnormal regulation of cortisol secretion, whether this aberrant expression also directly causes the development of a benign adrenocortical tumor is an open question. Cell transplantation provides a way to study genes that may be important in human tumor development. The system we developed uses genetically modified adrenocortical cells transplanted into adrenalectomized immunodeficient mice which form a functional tissue structure. We observed that enforcing expression of the gastric inhibitory polypeptide receptor or the luteinizing hormone receptor genes (taken as canonical examples of aberrantly expressed GPCRs) in adrenocortical cells resulted in the formation of hyperplastic tissues and the development of Cushing syndrome features in transplanted mice.
\end{abstract}




\section{Introduction}

The mammalian adrenal cortex secretes steroid hormones, particularly glucocorticoids, under the main control of adrenocorticotropin (ACTH). ACTH secreted from the anterior pituitary is in turn regulated by hypothalamic corticotrophin-releasing hormone $(\mathrm{CRH})$ and arginine vasopressin. This hypothalamo-pituitary-adrenal axis (HPA axis) is self-regulated by a negative feedback exerted by serum cortisol levels on both the hypothalamus and the pituitary gland. ACTH is also the main regulator of adrenal cortical growth. Its trophic action is mediated by a cohort of locally produced growth factors in the fetal adrenal (Mesiano et al., 1993) as well as in the adult adrenal (Ho and Vinson, 1995; Thomas et al., 2004). At the level of adrenocortical cells, ACTH binds to its cognate $\mathrm{MC} 2 \mathrm{R}$ (melanocortin type 2 receptor), a G protein-coupled receptor (GPCR) that ligand-dependently stimulates adenylyl cyclase (AC), cAMP-dependent protein kinase and transcription of cAMP-responsive genes (Mountjoy et al., 1992).

Cushing syndrome (CS) is the clinical manifestation of sustained hypercortisolism and is most frequently iatrogenic. Endogenous CS is a relatively rare disease and may be ACTH-dependent (80-85\% of cases) or ACTH-independent (1520\%) (Newell-Price et al., 1998). ACTH-independent CS is always caused by a primary adrenal disease associated with cortical hyperfunction. ACTH-independent CS is usually due to an adrenal adenoma or a carcinoma in the majority of cases but on rare occasions may be caused by other diseases, including primary pigmented nodular adrenal dysplasia (PPNAD) and ACTH-independent macronodular hyperplasia (AIMAH) (Stratakis and Kirschner, 1998; Doppman et al., 2000). Hypercortisolism leads to HPA axis feedback inhibition and adrenal cortisol production is maintained even in absence of ACTH by unknown mechanisms which are believed to be autonomous (Orth, 1991). However, works by several groups have shed light on the pathogenesis of hypercortisolism in some adenomas and AIMAH by showing that 
abnormal cortisol production is driven by other hormones than ACTH. Aberrant expression of GPCRs that are normally not present (ectopic expression) or expressed at much lower levels (over-expression) has been observed in adrenal CSs and proposed to be the cause for disregulated cortisol secretion. In these cases, hormone binding to its specific GPCR activates the AC/cAMP signaling cascade normally triggered by the $\mathrm{ACTH}$ receptor and then aberrantly stimulates corticosteroidogenesis and bypasses the physiological negative feedback mechanism exerted by glucocorticoids on the HPA axis. During the last decade, the GPCRs for gastric inhibitory polypeptide (GIP), catecholamines, vasopressin, serotonin, and luteinizing hormone/human chorionic gonadotropin $(\mathrm{LH} / \mathrm{hCG})$ have been shown to be involved in adrenal $\mathrm{CS}$ development (Lacroix et al., 2004). The molecular mechanisms responsible for aberrant expression of these receptors are however still unknown.

In some patients with ACTH-independent $\mathrm{CS}$, cortisol secretion can be controlled by blocking the aberrantly expressed receptor or by suppressing the ligand of the ectopic receptor (Reznik et al., 1992; de Herder et al., 1996; Lacroix et al., 1997). Such pharmacological treatments clearly improve the clinical and biological symptoms of these forms of CS. However, they do not induce any measurable regression of adrenal tumors.

Thus, the functional link between aberrant expression of hormone receptors and tumor development remains to be demonstrated. Is a single genetic change allowing aberrant GPCR expression the primary event that provokes both cortisol secretion and altered cell growth, resulting in the development of benign tumor? Is expression of the wild type receptor enough or is a mutation leading to a constitutively active receptor required to generate the observed phenotype?

\section{Transgenic adrenocortical tissues as a tool for tumorigenesis studies}


The lack of a suitable animal model for benign ACTH-independent adrenal tumor is the major obstacle for unraveling the role of aberrant GPCR expression in the pathogenesis of the disease. In order to tackle this issue, we used an in vivo model of cell transplantation and tissue reconstruction (Thomas et al., 1997; Thomas and Hornsby, 1999). In this model, primary bovine or human adrenocortical cells are transplanted under the kidney capsule of adrenalectomized immunodeficient mice reconstituting a vascularized and functional tissue, which secretes cortisol and avoids the otherwise lethal effect of adrenalectomy (Thomas and Hornsby, 1999; Thomas et al., 2002). The tissues formed are chimeric, composed of human or bovine adrenal cells together with mouse cells (endothelial cells lining the capillaries, fibroblasts and other cell types). Tissue reconstruction models differ from conventional assays in immunodeficient mice (subcutaneous or intra-muscular injection of cell suspension) in that the cell survival is not severely compromised by the implantation technique. If the cell survival is low, as it is in conventional assays, an undesired selection advantage might take place among the cells that would lead them to acquire a molecular phenotype different than the one of the general cell population. The fact that clonal bovine adrenocortical cells could form functional tissue following transplantation (Thomas et al., 1997) prompted us to genetically modify the cells prior transplantation. When genetically modified cells are used during transplantation procedures, they form what may be termed a transgenic tissue (Thomas et al., 2000; Thomas et al., 2002; Mazzuco et al., 2006a,b). The power of germ line genetic modification in the mouse to answer important biological questions is well established. For human cells, genetic modification in cell culture has been similarly powerful in elucidating human gene function. However, although germ line modification of humans is not an acceptable option, studying transgenic tissues containing human cells within experimental animals is acceptable and could prove useful to study how human genes function in such tissues 
in vivo. The ability of cell transplantation to create tissues expressing specific genes and gene combinations enables greater insight into the mode by which a protein by itself or in combination cooperates in benign or malignant transformation.

The rationale for the use of bovine cells is mainly due to the low availability of human cells. However, like human cells, bovine cells do not have telomerase activity sufficient for telomere maintenance and therefore undergo telomere shortening, leading to senescence (Thomas et al., 2000). Like human cells, they maintain a stable karyotype under long-term growth in culture. However, they have substantially longer telomeres than human cells (Kozik et al., 1998), enabling greater cell proliferation in the absence of telomerase, both in cell culture and in tissues formed from transplanted cells.

In the first set of experiments that used genetically modified cells, we showed that bovine adrenocortical cells immortalized by the introduction of hTERT (telomerase reverse transcriptase) formed functional tissue in mice that closely resemble that formed from non-genetically modified cells (Thomas et al., 2000). The tissue formed from the transplanted cells maintained normal growth control. However, in subsequent experiments, we showed that bovine adrenocortical cells modified with three genetic changes (hTERT, SV40 large T antigen, and oncogenic Ras) were tumorigenic (Thomas et al., 2002). While we believe these experiments are of interest in the context of a multistep model of tumorigenesis, they are also significant in that they provide a proof of principle that the formation of genetically modified tissues by transplantation of adrenocortical cells is feasible. When extended to human carcinoma development, we realized that the SV40 large T antigen expression is obviously not involved in human adrenal tumorigenesis, however this proof of principle let us envision that the experimental model was suitable for checking the transforming potential of genes of interest in tissues as opposed to common reductionist cell culture experiments. 


\section{Aberrant GPCRs expression and the formation of adrenocortical benign}

\section{tumors.}

Despite evidence accumulating on the aberrant regulation of cortisol secretion in ACTH-independent AIMAH and adenomas in which ectopic or eutopic GPCRs are over-expressed, little is known on the potential role of those receptors in the deregulated proliferation of adrenocortical cells and tumorigenesis. Thus, to address this critical point in the pathogenesis of the disease, we investigated the implication of the aberrant expression of the GIPR and the LHR in adrenal overgrowth (Mazzuco et al., 2006a,b).

GIP is a gastrointestinal hormone that is released during meals and acts on pancreatic $\beta$-cells to stimulate insulin release through binding to a seven-transmembrane domain GPCR (Lu et al., 1993). The GIPR gene is not expressed in the normal adrenal cortex (Usdin et al., 1993; Chabre et al., 1998). Ectopic GIPR expression in the adrenal cortex is observed in food-dependent CS in which plasma cortisol levels are low or normal during fasting and increase following a meal (Lacroix et al., 1992; Reznik et al., 1992).

The LHR, which binds both LH and hCG, plays a crucial role in the development of both male and female gonads and in the ovulation in females (Ascoli et al., 2002). In the normal adrenal cortex, LHR is expressed in the zona reticularis, and hCG stimulates the production of dehydroepiandrosterone sulfate from fetal but not from adult adrenal cells (Seron-Ferre et al., 1978; Pabon et al., 1996). The aberrant adrenal function of LHR was first described in a woman with transient CS during pregnancies (high circulating hCG) and persistent CS after menopause (high circulating LH) (Lacroix et al., 1999). It is noteworthy that most cases of LH/CG-R gene overexpression were associated with other GPCRs (Lacroix et al., 1999; Feelders et al., 2003; Miyamura et al., 2003; Bertherat et al., 2005). The co-expression of at least two GPCRs made it difficult to draw any conclusions on the relative involvement of either 
receptors or a possible GPCRs cooperation on the development of CS secondary to a hyperplasia.

The GIPR and LHR complementary DNAs were cloned in a retroviral vector chosen for its ability to integrate into the cell genome, permitting long-term transgene expression in the transduced cells and their progeny (Mazzuco et al., 2006a,b). The expression of either transgene does not induce phenotypic modifications in vitro of the transduced cells as compared to primary cells or cells transduced with an empty vector specifying only a drug resistance gene (control cells). Before transplantation, we verified the functional status of our transgenes. As both receptors mainly activate the Gs/AC/cAMP/PKA pathway, we measured the cAMP production. Upon ACTH (100 $\mathrm{nM}$ ) stimulation, all infected cells (eg, control, GIPR and LHR cells) show a 7-fold increase in cAMP production, whereas upon either GIP $(100 \mathrm{nM})$ for the GIPR cells or hCG $(10 \mathrm{IU} / \mathrm{ml})$ for the LHR cells, cAMP production is induced by $16-$ and 8 -fold, respectively (Mazzuco et al., 2006a,b). In contrast, cAMP levels are not modified in control cells by either GIP or hCG treatment. In adrenocortical cells, activation of the Gs/AC/cAMP/protein kinase A by ACTH results in an acute stimulation of cortisol secretion. In response to $\mathrm{ACTH}$, all cell types produce twice as much cortisol as the unstimulated cells. By contrast, under GIP or hCG treatment, only the GIPR or LHR cells show a 2-fold elevation of cortisol secretion, respectively. Thus, the enforced expression of GIPR or LHR gene in adrenocortical cells is efficiently coupled to steroidogenesis and is responsible for abnormal cortisol secretion. Several in vitro studies using primary cell cultures derived from human adrenal tumors associated with aberrant GPCR expression have established that those receptors confer steroidogenic response to the corresponding ligands and substitute for the MC2R function (Lacroix et al., 1992; Horiba et al., 1995; Lacroix et al., 1997; Chabre et al., 1998). 
The site for cell transplantation is beneath the kidney capsule of RAG2-/immunodeficient mice. Bilateral adrenalectomy and cell transplantation are performed in the same surgical procedure. After 4 weeks, tail blood samples are taken at weekly interval under anesthesia at basal time and 15 min after the i.p. injection of ACTH, GIP or hCG according to the implanted cell type. As summarized in Table 1, the control mice increase their level of cortisol secretion only after ACTH challenge whereas the GIPR mice respond to both ACTH and GIP injection and, the LHR mice to both ACTH and hCG injection. Moreover, the basal plasma cortisol concentration is higher by $86 \%$ in LHR mice than control mice while the basal plasma ACTH concentration in LHR mice was inhibited by $68 \%$ in comparison with control mice whereas, in the GIPR mice the basal ACTH level is down by $48 \%$ with unchanged basal cortisol level as compared to the control mice.

Following sacrifice, the kidneys bearing transplanted cells were excised and analyzed macroscopically (Fig 1). Control cells form a thin tissue lying on the top of the kidney parenchyma. In contrast, transplanted GIPR and LHR cells give rise to voluminous masses, much thicker than control neo-organs. A compression of the renal parenchyma is visible in the cases of GIPR and LHR transplants (Fig 1). Histologically, 8 weeks after transplantation, control adrenocortical cells formed a small tissue in marked contrast to the voluminous tissues formed by GIPR and LHR cells although $2 \times 10^{6}$ cells had been initially transplanted in all cases (Fig 1). GIPR and LHR tissues formed a heterogeneous hyperplastic expanding masses constituted of both clear, lipidladen cells and eosinophilic lipid-depleted cells. Both transplant tissues showed an irregular architecture with cellular pleomorphism and nuclear atypia (Fig 1) interspersed with stroma which was more pronounced in the GIPR tissues (Mazzuco et al., 2006a). The contact between adrenocortical tissues and the kidney surface was preserved with no sign of invasion (Fig 1). 
To further characterize the enlargement of GIPR and LHR tissues as compared to control tissue, we checked whether cellular hyperplasia result from increased proliferation. The proliferation rate of control, GIPR and LHR cells in the transplant tissues at day 50 following transplantation was assessed by immunostaining for the Ki67 proliferation-associated protein. The Ki-67 labeling index was significantly higher in GIPR and LHR cells $(17.7 \pm 1.3 \%$ in GIPR transplants and $13.3 \% \pm 1.8 \%$ in LHR transplants $v s .3 .5 \% \pm 1.0 \%$ in control transplants, $\mathrm{p}<0.001$ and $\mathrm{p}=0.002$, respectively, Fig 2). This result emphasizes the notion that hyperplasia in adrenocortical GIPR and LHR tissues was at least due to a growth advantage induced by aberrant expression of the GIPR and LHR gene. The rare in vitro studies using cells derived from human pathological samples have reported opposite results. Our group reported previously that GIP could weakly stimulate mitogen-activated protein kinase activity and thymidine incorporation in adrenocortical cells from an adenoma of a patient with food-dependent CS (Chabre et al., 1998). Conversely, GIP has been shown to inhibit thymidine incorporation in adrenocortical cells isolated from a food-dependent adenoma (Lebrethon et al., 1998). This type of analysis has unfortunately not been performed in other cases of CS secondary to aberrant GPCR expression. How can stimulation of GIPR in adrenocortical cells lead to cellular hyperplasia, hypertrophy and pleomorphism with stromal reaction, as obtained in GIPR and LHR transplants? The most evident but quite vague answer to this question is that GIP and $\mathrm{LH} / \mathrm{hCG}$ act through the same pathways as ACTH. It is long known that in vivo an excess of endogenous or exogenous ACTH causes adrenal hypertrophy, rapidly followed by hyperplasia (Dallman, 1984), while in vitro studies using adrenal cells from several species have shown that $\mathrm{ACTH}$ behaves as antimitogenic leading to the notion that ACTH is an indirect mitogen in intact animals (Hornsby, 1984). A link between adenylyl cyclase activation and adrenocortical cell proliferation certainly exists, 
probably involving such paracrine mediators acting directly or indirectly. A gene array analysis on AIMAH has shown that several over-expressed genes encode proteins playing a role in cell cycle control (Bourdeau et al., 2004).

Finally, our mouse models allowed us to investigate whether the growth of the GIPR transplants was ACTH-independent. ACTH secretion was suppressed by s.c. perfusion of dexamethasone from the onset of transplantation. When dexamethasonetreated animals transplanted with control adrenocortical cells were sacrificed after 14 days, an atrophic transplant tissue was present at the site of injection with reduced cellularity and disorganized architecture as compared to untreated control mice. In contrast, GIPR transplants developed similarly in the presence or in the absence of ACTH. The development of GIPR tumors independently of ACTH secretion indicated that physiologically secreted GIP is likely to act as a trophic factor through activation of the adrenal ectopic GIPR.

\section{Conclusions}

The cell transplantation system described here has the potential for reconstructing normal adrenocortical tissue from component cells and for studying factors which regulate the size, proliferation, differentiation and vascularization of tissues. Combined with the ability to genetically modify cells prior to transplantation, this system provides a complementary method for the study of gene action within tissues. Cell transplantation combined with genetic modification gives an opportunity for studies which neither directly reproduce those of germ line modification of animals or of genetic modification of cells in vitro. The use of tissues in an experimental animal enables innovative tests to be performed, which obviously cannot be done in cell culture. In that respect, we have demonstrated that the aberrant expression of a non- 
mutated G protein-coupled receptor gene is a sufficient primary genetic event to initiate a gain-of-function leading to adrenocortical cell transformation (Fig 3).

This field of research combines cell transplantation with established and emerging methods of genetic modification of somatic bovine and human cells. As this approach is developed, we plan to extend these studies to other genes of interest for human adrenal pathology and to study the action of such genes in human tissue in this cell transplantation model.

\section{Acknowledgments}

We thank Dr. T. Usdin for the plasmid pCMV IRES rGIPR and Pr. P. Rodien for the plasmid pcDNA3 LHR. This work was supported by INSERM, CEA (DSV/DRDC/ANGIO), Fondation de France (research grant 2004012837 to M.T.), Association pour la Recherche sur le Cancer (ARC, France, research grant 4713 to M.T.), Programme Hosptalier de Recherche Clinique (Grant AOM 02068) to the COMETE Network and GEFLUC (Département de l'Isère). T.L.M. was a post-doctoral fellow from National Council for Scientific and Technological Development (CNPq, Brazil).

\section{References}

Ascoli, M., Fanelli, F., Segaloff, D.L., 2002. The lutropin/choriogonadotropin receptor, a 2002 perspective. Endocr Rev 23, 141-74.

Bertherat, J., Contesse, V., Louiset, E., Barrande, G., Duparc, C., Groussin, L., Emy, P., Bertagna, X., Kuhn, J.M., Vaudry, H., Lefebvre, H., 2005. In vivo and in vitro screening for illegitimate receptors in adrenocorticotropin-independent macronodular adrenal hyperplasia causing Cushing's syndrome: identification of 
two cases of gonadotropin/gastric inhibitory polypeptide-dependent hypercortisolism. J Clin Endocrinol Metab 90, 1302-10.

Bourdeau, I., Antonini, S.R., Lacroix, A., Kirschner, L.S., Matyakhina, L., Lorang, D., Libutti, S.K., Stratakis, C.A., 2004. Gene array analysis of macronodular adrenal hyperplasia confirms clinical heterogeneity and identifies several candidate genes as molecular mediators. Oncogene 23, 1575-85.

Chabre, O., Liakos, P., Vivier, J., Chaffanjon, P., Labat-Moleur, F., Martinie, M., Bottari, S.P., Bachelot, I., Chambaz, E.M., Defaye, G., Feige, J.J., 1998. Cushing's syndrome due to a gastric inhibitory polypeptide-dependent adrenal adenoma: insights into hormonal control of adrenocortical tumorigenesis. J Clin Endocrinol Metab 83, 3134-43.

Dallman, M.F., 1984. Control of adrenocortical growth in vivo. Endocr Res 10, 213-42. de Herder, W.W., Hofland, L.J., Usdin, T.B., de Jong, F.H., Uitterlinden, P., van Koetsveld, P., Mezey, E., Bonner, T.I., Bonjer, H.J., Lamberts, S.W., 1996. Fooddependent Cushing's syndrome resulting from abundant expression of gastric inhibitory polypeptide receptors in adrenal adenoma cells. J Clin Endocrinol Metab $81,3168-72$.

Doppman, J.L., Chrousos, G.P., Papanicolaou, D.A., Stratakis, C.A., Alexander, H.R., Nieman, L.K., 2000. Adrenocorticotropin-independent macronodular adrenal hyperplasia: an uncommon cause of primary adrenal hypercortisolism. Radiology $216,797-802$.

Feelders, R.A., Lamberts, S.W., Hofland, L.J., van Koetsveld, P.M., Verhoef-Post, M., Themmen, A.P., de Jong, F.H., Bonjer, H.J., Clark, A.J., van der Lely, A.J., de Herder, W.W., 2003. Luteinizing hormone (LH)-responsive Cushing's syndrome: the demonstration of $\mathrm{LH}$ receptor messenger ribonucleic acid in hyperplastic adrenal 
cells, which respond to chorionic gonadotropin and serotonin agonists in vitro. $\mathrm{J}$ Clin Endocrinol Metab 88, 230-7.

Ho, M.M., Vinson, G.P., 1995. Endocrine control of the distribution of basic fibroblast growth factor, insulin-like growth factor-I and transforming growth factor-beta 1 mRNAs in adult rat adrenals using non-radioactive in situ hybridization. $\mathbf{J}$ Endocrinol 144, 379-87.

Horiba, N., Suda, T., Aiba, M., Naruse, M., Nomura, K., Imamura, M., Demura, H., 1995. Lysine vasopressin stimulation of cortisol secretion in patients with adrenocorticotropin-independent macronodular adrenal hyperplasia. J Clin Endocrinol Metab 80, 2336-41.

Hornsby, P.J., 1984. Regulation of adrenocortical cell proliferation in culture. Endocr Res $10,259-81$.

Kozik, A., Bradbury, E.M., Zalensky, A., 1998. Increased telomere size in sperm cells of mammals with long terminal (TTAGGG)n arrays. Mol Reprod Dev 51, 98-104.

Lacroix, A., Bolte, E., Tremblay, J., Dupre, J., Poitras, P., Fournier, H., Garon, J., Garrel, D., Bayard, F., Taillefer, R., et al., 1992. Gastric inhibitory polypeptidedependent cortisol hypersecretion--a new cause of Cushing's syndrome. N Engl J Med 327, 974-80.

Lacroix, A., Tremblay, J., Rousseau, G., Bouvier, M., Hamet, P., 1997. Propranolol therapy for ectopic beta-adrenergic receptors in adrenal Cushing's syndrome. N Engl J Med 337, 1429-34.

Lacroix, A., Hamet, P., Boutin, J.M., 1999. Leuprolide acetate therapy in luteinizing hormone-dependent Cushing's syndrome. N Engl J Med 341, 1577-81.

Lacroix, A., Baldacchino, V., Bourdeau, I., Hamet, P., Tremblay, J., 2004. Cushing's syndrome variants secondary to aberrant hormone receptors. Trends Endocrinol Metab 15, 375-82. 
Lebrethon, M.C., Avallet, O., Reznik, Y., Archambeaud, F., Combes, J., Usdin, T.B., Narboni, G., Mahoudeau, J., Saez, J.M., 1998. Food-dependent Cushing's syndrome: characterization and functional role of gastric inhibitory polypeptide receptor in the adrenals of three patients. J Clin Endocrinol Metab 83, 4514-9.

Lu, M., Wheeler, M.B., Leng, X.H., Boyd, A.E., 3rd, 1993. The role of the free cytosolic calcium level in beta-cell signal transduction by gastric inhibitory polypeptide and glucagon-like peptide I(7-37). Endocrinology 132, 94-100.

Mazzuco, T.L., Chabre, O., Sturm, N., Feige, J.J., Thomas, M., 2006a. Ectopic expression of the gastric inhibitory polypeptide receptor gene is a sufficient genetic event to induce benign adrenocortical tumor in a xenotransplantation model. Endocrinology 147, 782-90.

Mazzuco, T.L., Chabre, O., Feige, J.J., Thomas, M., 2006b. Aberrant expression of human luteinizing hormone receptor by adrenocortical cells is sufficient to provoke both hyperplasia and Cushing's syndrome features. J Clin Endocrinol Metab 91, 196-203.

Mesiano, S., Coulter, C.L., Jaffe, R.B., 1993. Localization of cytochrome P450 cholesterol side-chain cleavage, cytochrome P450 17 alpha-hydroxylase/17, 20lyase, and 3 beta-hydroxysteroid dehydrogenase isomerase steroidogenic enzymes in human and rhesus monkey fetal adrenal glands: reappraisal of functional zonation. J Clin Endocrinol Metab 77, 1184-9.

Miyamura, N., Tsutsumi, A., Senokuchi, H., Nakamaru, K., Kawashima, J., Sakai, K., Taguchi, T., Tokunaga, H., Nishida, K., Uehara, M., Sakakida, M., Araki, E., 2003. A case of ACTH-independent macronodular adrenal hyperplasia: simultaneous expression of several aberrant hormone receptors in the adrenal gland. Endocr J 50, $333-40$ 
Mountjoy, K.G., Robbins, L.S., Mortrud, M.T., Cone, R.D., 1992. The cloning of a family of genes that encode the melanocortin receptors. Science 257, 1248-51.

Newell-Price, J., Trainer, P., Besser, M., Grossman, A., 1998. The diagnosis and differential diagnosis of Cushing's syndrome and pseudo-Cushing's states. Endocr Rev 19, 647-72.

Orth, D.N., 1991. Differential diagnosis of Cushing's syndrome. N Engl J Med 325, $957-9$

Pabon, J.E., Li, X., Lei, Z.M., Sanfilippo, J.S., Yussman, M.A., Rao, C.V., 1996. Novel presence of luteinizing hormone/chorionic gonadotropin receptors in human adrenal glands. J Clin Endocrinol Metab 81, 2397-400.

Reznik, Y., Allali-Zerah, V., Chayvialle, J.A., Leroyer, R., Leymarie, P., Travert, G., Lebrethon, M.C., Budi, I., Balliere, A.M., Mahoudeau, J., 1992. Food-dependent Cushing's syndrome mediated by aberrant adrenal sensitivity to gastric inhibitory polypeptide. N Engl J Med 327, 981-6.

Seron-Ferre, M., Lawrence, C.C., Jaffe, R.B., 1978. Role of hCG in regulation of the fetal zone of the human fetal adrenal gland. J Clin Endocrinol Metab 46, 834-7.

Stratakis, C.A., Kirschner, L.S., 1998. Clinical and genetic analysis of primary bilateral adrenal diseases (micro- and macronodular disease) leading to Cushing syndrome. Horm Metab Res 30, 456-63.

Thomas, M., Northrup, S.R., Hornsby, P.J., 1997. Adrenocortical tissue formed by transplantation of normal clones of bovine adrenocortical cells in scid mice replaces the essential functions of the animals' adrenal glands. Nat Med 3, 978-83.

Thomas, M., Hornsby, P.J., 1999. Transplantation of primary bovine adrenocortical cells into scid mice. Mol Cell Endocrinol 153, 125-36. 
Thomas, M., Yang, L., Hornsby, P.J., 2000. Formation of functional tissue from transplanted adrenocortical cells expressing telomerase reverse transcriptase. Nat Biotechnol 18, 39-42.

Thomas, M., Suwa, T., Yang, L., Zhao, L., Hawks, C.L., Hornsby, P.J., 2002. Cooperation of hTERT, SV40 T antigen and oncogenic Ras in tumorigenesis: a cell transplantation model using bovine adrenocortical cells. Neoplasia 4, 493-500.

Thomas, M., Keramidas, M., Monchaux, E., Feige, J.J., 2004. Dual hormonal regulation of endocrine tissue mass and vasculature by adrenocorticotropin in the adrenal cortex. Endocrinology 145, 4320-9.

Usdin, T.B., Mezey, E., Button, D.C., Brownstein, M.J., Bonner, T.I., 1993. Gastric inhibitory polypeptide receptor, a member of the secretin- vasoactive intestinal peptide receptor family, is widely distributed in peripheral organs and the brain. Endocrinology 133, 2861-70. 
Table 1 Relative changes of plasma cortisol levels in transplanted mice after ACTH, GIP or hCG injection.

\begin{tabular}{|c|c|c|c|c|}
\hline \multirow[t]{2}{*}{ In vivo tests } & \multicolumn{3}{|c|}{ Mean (+/- SD) of cortisol response ( $\%$ of basal) } & \multirow{2}{*}{$\begin{array}{c}P \\
\text { values }\end{array}$} \\
\hline & Control mice & GIPR mice & LHR mice & \\
\hline ACTH (42 pmol/g) & $126+/-24(n=4)$ & $126+/-24(\mathrm{n}=4)$ & $172+/-24(\mathrm{n}=3)$ & NS \\
\hline GIP (50 pmol/g) & $90+/-6 \quad(n=5)$ & $144+/-21(\mathrm{n}=11)$ & & $<0.05$ \\
\hline $\mathrm{hCG}(0.5 \mathrm{IU} / \mathrm{g})$ & $92+/-2 \quad(n=3)$ & nd & $245+/-57(n=3)$ & $<0.05$ \\
\hline
\end{tabular}

In vivo tests were performed by the i.p. injection of each peptide as indicated. Blood samples were collected at basal and 15 minutes after peptide injection and the cortisol response was calculated as percentage of basal plasma cortisol levels.

NS, non significant.

$n d$, not determined.

Adapted from data from Mazzuco et al., 2006a,b. 


\section{Legends of figures}

Figure 1 Morphological and histological appearances of tissues formed by transplantation of control cells and, GIPR and LHR-modified bovine adrenocortical cells. Macroscopic view shows representative axial sections of adrenocortical tissues formed beneath the renal capsule, obtained at the sacrifice of mice. Microscopic view displays hematoxylin and eosin-stained examples of transplants. Magnification x200. The kidney parenchyma and capsule may be seen only in the control tissue. A, adrenocortical tissue; K, kidney; C, renal capsule. Adapted from data from Mazzuco et al., 2006a,b.

Figure 2 Box-and-whisker plot of labeling proliferation index assessed by expression of Ki-67 antigen in adrenocortical tissues formed 8 weeks following transplantation of control, GIPR and LHR cells. ${ }^{* *}, P<0.01$ vs. control; ***, $P<0.001$ vs. control; $\mathrm{n}=10$ tissue sections. Adapted from data from Mazzuco et al., 2006a,b.

Figure 3 Proposed model of genetically modified adrenocortical cells transplantation leading to ACTH-independent transgenic tissue formation and aberrant GPCR-induced tumorigenesis. Transplantation of normal adrenocortical cells in adrenalectomized mice originates a functional ACTH-dependent adrenocortical tissue. Normal tissue formation does not occur if plasma ACTH is suppressed. The tissue formed from adrenocortical cells over-expressing GPCR produces cortisol in response to physiological levels of GPCR ligand (e.g., post-prandial GIP secretion or pulsatile pituitary LH secretion), and the ACTH secretion can be diminished. GPCR aberrant expression induces proliferation and growth of the tissue formed following transplantation, qualifying a benign tumor. Ectopic or over- GPCR expression is the cause of these tumors and its activation is not counterbalanced by a feedback control on adrenal cortex. 


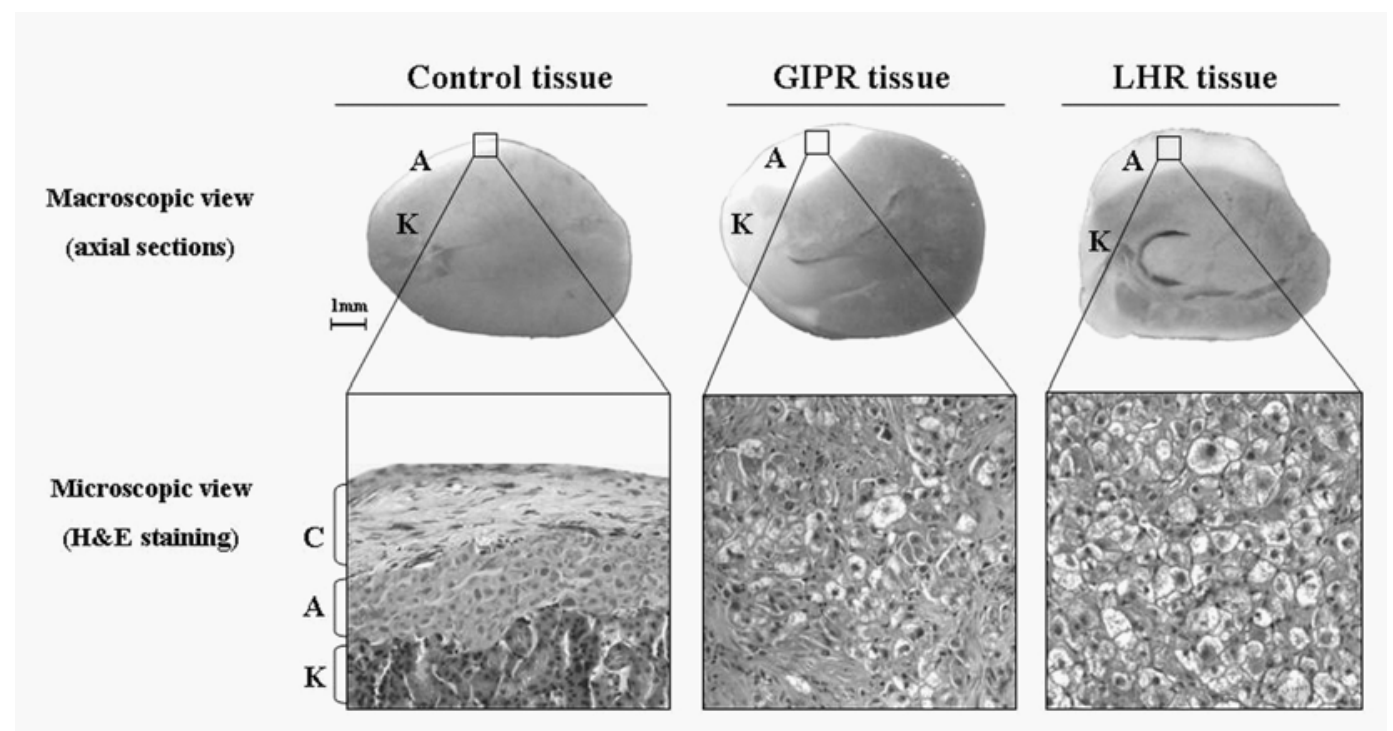




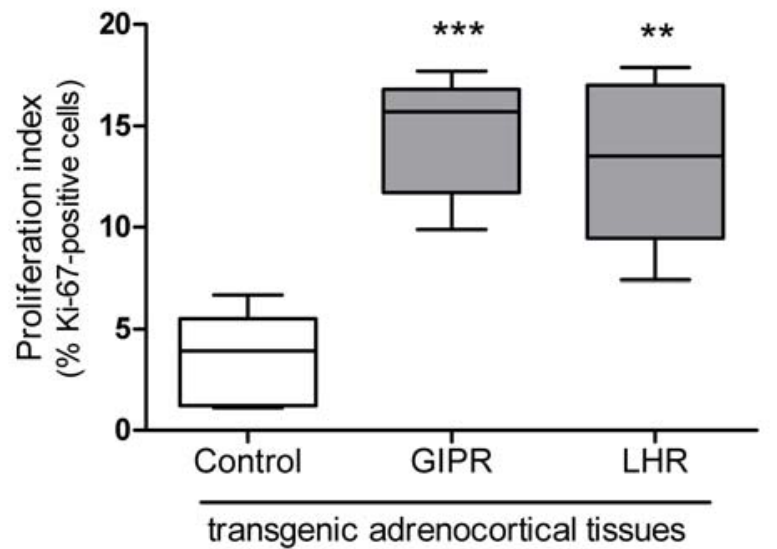




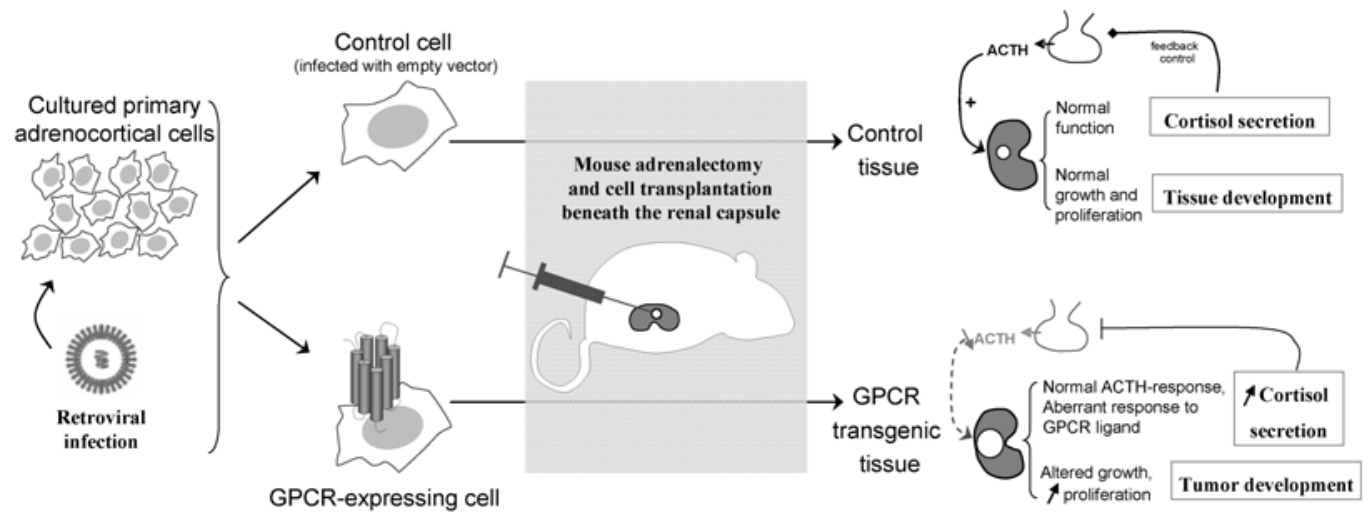

